\title{
Price Policies, Over-Supply and Demand Bubbles
}

\author{
Giuseppe Cappiello*
}

\begin{abstract}
In the current conditions of over-supply, firms are paying high attention to pricing decisions in order to defend their competitive positioning.

Modern pricing strategies are able to take into account changed market conditions or, in other words, demand characterised by strong volatility and non loyal behaviour flanking known loyalty mechanisms.

Moreover, suppliers are also looking for innovative formulas to determine the exchange relationship with the customer and price is increasingly seen as a 'catalyser' of continuously changing offers in relation to market conditions (demand bubble).
\end{abstract}

Keywords: Global Markets, Marketing; Price Policies; Over-Supply; Demand Bubbles

\section{Over-Supply and Price Policies}

Firms are paying maximum attention to price leverage, for their own competitive positioning, in the current conditions of oversupply, increased competition space and pre-eminent importance of the intangible components of supply (Brondoni, 2002).

Service firms, in particular, as they generate intangible and perishable outputs, in other words outputs that cannot be stored for supply at a later time, find themselves having to match rigid productive capacity with instable demand.

Even in the public utility industry where tariffs have always been defined by legislation ${ }^{1}$, rather than by commercial and marketing strategy, important changes are happening ${ }^{2}$ and a whole new season is opening up, in which operators will enter into competition with one another and managerial efficiency will have to be pursued alongside customer satisfaction and the development of regulations to safeguard public interest (Borgonovi, 1996).

\footnotetext{
* Assistant Professor of Management, Alma Mater Studiorum-University of Bologna (giuseppe. cappiello@unibo.it)
} 
Moreover, they are also looking for innovative formulas to determine the exchange relationship with the customer and price is increasingly seen as a 'catalyser' of continuously changing offers in relation to market conditions (bubble demand).

Finally, the customer is in a much more favourable position now, compared to some time ago, thanks to oversupply and the availability of more information which make it possible to tend to negotiate terms and conditions of purchase, up to the point of determining them ${ }^{3}$.

\section{Evolution of Information Technologies and Price Policies}

Several strategies and techniques for price definition and management have been developed over the last few years, which tend to increase productive capacity occupation rates without having to reduce sales prices. Modern pricing strategies are able to take into account changed market conditions or, in other words, demand characterised by strong volatility and 'non loyal behaviour flanking known loyalty mechanisms ${ }^{4}$.

In bundled offers, i.e. offers composed of several products, different goods or services are assembled into a single proposal with a generally lower price than the sum of the prices of the single components of the supply. In this way an attempt is made to reduce part of the cost, supply greater value, attack new markets, transfer share of demand towards periods of lower request, increase average expenditure of current customers, and generally to encourage price personalisation (Stigler 1963; Guiltinan, 1987, Stremersch\&Tellis, 2002). Travel agents offer holiday packages in their catalogues which include accommodation, transport and sometimes even some excursions; telephone services or commercial services companies propose credit cards and correlated financial services in order to facilitate consumption and acquire new customers. Trading firms offer compositions of products and services, including some that are perhaps very different to one another, in order to break consolidated loyalty links with competing firms.

With the use of Yield Management practices - meaning an attempt to increase the yield of production capacity in terms of expected income - introduced initially by airline companies and then adopted in other spheres such as the hotel, health and electricity supply sectors, the intention is rather to optimise the allocation of resources, starting from the different composition of market demand.

Operatively speaking, with Yield Management, by making use of marginal income models, the number of production units to be assigned to each class of service is defined in relation to expected request (Kimes, 1989; Smith et al, 1992; Beretta et al, 2000).

In service production, different outputs can be achieved only at the time of fabrication the services environment (referring yet again to transport of people, the difference between first and second class seating can be made only at the time of the aircraft fabrication) whereas a commercial offer, for the purchase of a place in one of the aforesaid seats, can be tied in to various conditions (type of service, day of the week, possibility of changing the booking, etc.) and for this reason it can be composed of different prices. Thanks to the diffusion of information technologies on wide scale and their greatly contained prices (smart cards, electronic tickets), some 
suppliers of services try to separate the time of purchase from that of consumption of the service (advance selling), think for instance of prepaid telephone cards or credit cards, or of the books of tickets for a certain number of discotheque or theme park entrances (Shugan\&Xie, 2001; Lee\&Ng, 2001). In all honesty, a large number of services include advance remuneration with respect to fruition time, but in this case the intention is to put greater emphasis on the distance in terms of time between the two events. As well as the benefits in financial and cash flow terms, bringing purchase time forward may favour use of the service from a technical and operative viewpoint, acquire greater availability to pay on the part of those customers who intend to guarantee themselves a ticket or the service and reduce uncertainty regards the actual service desired. For the seller too, obtaining information in advance on the trend in demand constitutes a resource of absolute importance. Advance sales strategy may be adopted in an exclusive manner or combined with the regular method of purchase at the time of consumption or included in a Yield Management programme. Basically, it is a case of identifying behaviours, motivations, conditions of use and priorities in the use of the service on the part of the customer, for the purpose of formulating supplies which can be perceived to be of greater value at a determinate moment of purchase.

The spread of the use of online auctions, in other words those methods of sale via the Internet, which assign goods or service without having a predefined price (posted price), appears to introduce an element of novelty and better explain what is implicitly present in what has just been described. In the dynamics of auctions there is a bidirectional aspect between demand and supply in as far as potential buyers choose the price at which to make an exchange and the market answers. In using the internet site priceline.com the purchaser indicates his/her own willingness to pay for a holiday package or a simple overnight stay and in a short space of time the connected firms decide whether or not to accept the proposal made by the customer; some American sports teams put tickets for matches up for auction in the days immediately preceding the match itself directly on the team's own site and fans purchase them by credit card when the price is at the desired level.

Some online auction sites ask people to indicate their own price limit and automatically re-launch until the time when the auction reaches that figure, after which it is up to the purchaser to decide whether or not to continue with the auction. Techniques for running auctions are varied and sometimes sophisticated (English, Dutch, sealed bid-first price, sealed bid-second price etc.) but all share the intention of getting as near as possible to the reservation price of the individual purchasers ${ }^{5}$.

The above seems to bear out the hypothesis whereby as the offers and quantities of information available to the customer increase, in real time and in interactive format (digital economy), it is perhaps the very same customers who 'self segment themselves'; in actual fact the segmentation process is no longer unidirectional (the firm analyses the market and proposes different supplies for defined homogeneous groups of customers) but bidirectional (a market offer attracts customers with purchase habits which may be very different to one another and over time). In this hypothesis the customer chooses each time whether or not to accept the supply by adopting differentiated behaviours according to personal situation, market situation and information status (prices chosen by demand) (Cappiello, 2002a). 


\section{Price and Demand Bubble}

The examples given indicate that in actual circumstances sale price plays a determining role both in the composition of profit and in the customer's cognitive system. When market competition conditions show substantial equilibrium between demand and supply, price is the result of a product differentiation process performed only after having identified in the market groups of purchasers with homogeneous preferences (segmentation).

In those situations in which supply has exceeded demand for services, due to legislative changes or the arrival of new competitors, (think of the end of a monopoly by a state operator in some public services or the availability of new tourist destinations following changes in the international political scene), the stability in behaviour which allows identification of a market segment ceases to exist (Brondoni, 2001).

At this point the customer, although on the one hand more prone to impulse purchases (Rook, 1987; Cappiello\&Cesari, 2005), on the other manoeuvres with great ease amongst different supplies and is ever more inclined to negotiate purchase terms. Therefore in times of oversupply, traditional market segments are flanked by 'temporary groupings of purchasers which may be aggregated on the basis of sharing specific characteristics of a given corporate offer, ${ }^{6}$ i.e. a demand bubble which has to be managed by the firm.

Demand bubble creation is favoured by the actual firm itself in as far as it possesses the requisites for same, or to be more precise, an information system capable of obtaining the necessary information about demand, a consistent brand equity as far as market relations status is concerned and a corporate mindset capable of living with market instability (Corniani, 2004). Suffice it to think of summer promotions of subscriptions to pay television channels, to mobile telephones or to special offers for some tourist destinations: the price is a feature of both attraction and composition of the various versions of the offer.

\begin{tabular}{|c|c|c|}
\hline Pricing strategy & Provides value by & Implemented as \\
\hline & Generating a more & Service bundling \\
Demand-bubble & Yield Management \\
pricing & valuable market-bubble & Advance selling \\
& at the right moment & Auctions \\
\hline
\end{tabular}

In this context then time is a determining variant both with reference to speed in relating to the market - time to market - and to valorisation of the use of time time value - (Brondoni\&Giulivi, 1993). The choice of time is even more important in consideration of the extreme simplicity of being imitated by competitors and losing an acquired competitive advantage. To summarize in extreme, it appears correct to say that even in the field of services, firms try to create temporary bubble demand in order to capture a different willingness to pay on the part of purchasers and break habitual loyalty relationships between firm and customer, right up to the point of adopting specific price policies that hold that critical success factor in their time span. 


\section{Price and Consumer Behaviour}

Differentiation of offers is intended to favour a more stable relationship with the customer who finds the service corresponds ever more to his/her own requests and willingness to pay; on the other hand that very same relationship could be undermined by a perception of opportunistic behaviour in as far as the realisation of many versions of a service has its conceptual and operative basis in price discrimination. The value of a product or service is commonly appraised in the ratio between acquired benefits and sacrifice incurred, monetary or non monetary. Martins and Monroe (1994) uphold that the perception of non equity in price (price fairness) influences perception of the sacrifice and of the value of the product, affecting willingness to purchase.

Studies which have looked at customer satisfaction as a necessary condition to establish a lasting relationship with the customer, have put fairness as a determining factor in appraisal of the economic exchange (Oliver\&Swan, 1989), especially in cases of service failure such as for instance, overbooking, a sudden unavailability of I.T. connections or of service support equipment, underestimation of urgency. Moreover it must be noted that social psychology and economic psychology studies indicate that wherever the consumer feels they have been treated in an unfair manner, same will react by attempting to re-establish a form of justice, even by incurring further costs, and trying on the one hand to 'punish' the other party and be reimbursed and on the other to limit any future repetition of such behaviour (Adams, 1965). In particular:

- perception of the unfairness of a firm's actions is proportional to the increase made in the price system;

- the greater the perception of unfairness, greater will the probability of retaliation towards the firm be;

- the probability of retaliation is inversely proportional to the cost of its implementation (Piron\&Fernandez, 1995).

Kahneman, Knetsch e Thaler (1986) introduced the principle of 'Dual Entitlements' according to which a firm is acknowledged the power, by consumers, to increase price levels in order to maintain its current profit levels, (for example when the firm has sustained an increase in costs), whilst it is considered unfair to increase prices only to achieve greater profits; but when a firm, in the course of its business, records a decrease in costs, consumers deem it fair to maintain price levels unaltered.

\section{Conclusions}

The spreading of digital technology and more generally the development of the so called 'new economy' seemed to lead towards a return to perfect competition with full information available to economic operators and a downwards crushing of price levels. Actually this hypothesis appears to be denied and firms apply a strong differentiation, based on the intangible components of supply and above all on price level (Ancarani, 2004). 
At the same time it has been demonstrated that the use of price strategies and efficient techniques for the implementation of strategies leads, in the short term, to an increase in revenue (Marn\&Rosiello, 1992; Nagle\&Holden, 1995; Dolan\&Simon, 1996) and to the realisation of an almost infinite number of versions of service supply capable of satisfying demand expectations.

Currently, proliferation of supplies which greatly exceed the market's absorption capacity tends to develop specific price policies; in particular we are witness to the realisation of ever more differentiated supplies (price discrimination) where time is the pre-eminent variable and it is the customer who (more or less consciously) contributes to the 'planning' of the supply. In creating demand bubble a firm must not, however, lose sight of the fact that the customer has learnt to manage amongst different proposals, and therefore care must be taken to avoid causing any perception of adopting opportunistic and non-transparent conduct.

\section{Bibliography}

Adams J.S., Inequity in Social Exchange, Advances in Experimental Social Psychology, 1965. http://dx.doi.org/10.1016/S0065-2601(08)60108-2

Ancarani F., Il prezzo in rete, Etas, 2004.

Beretta M. et al., Yield Management, Economia \& Management, n. 2, 2000.

Borgonovi E., Le nuove frontiere dei servizi pubblici tra soddisfazione dell'utente e tutela dell'interesse pubblico, Sinergie, n. 41, 1996.

Brondoni S. M., Giulivi A, Competizione time-based e nuova progettualità della comunicazione aziendale, Quaderno di Sinergie, n. 9, 1993.

Brondoni S. M., Comunicazione, risorse invisibili e strategia competitive d'impresa, Sinergie, nn. 43-44, 1997.

Brondoni S. M., Global Markets and Market-Space Competition, Symphonya. Emerging Issues in Management (symphonya.unimib.it), n. 1, 2002. http://dx.doi.org/10.4468/2002.1.03brondoni

Cappiello G., Auction Pricing and Market-Space Competition, Symphonya. Emerging Issues in Management (symphonya.unimib.it), n. 1, 2002.

http://dx.doi.org/10.4468/2002.1.11cappiello

Cappiello G., Pricing (fairly) Market Bubble, Proceedings of the 8th International Research Seminar in Service Management, La Londe, 2004.

Cappiello G., Cesari A., Impulse buying and pricing policy, Proceeding of the 7th Annual Fordham Pricing Conference, New York, 2005.

Corniani M., Segmentazione e aggregazione della domanda aziendale, Giappichelli, Turin, 2004.

Guiltinan J., The Price Bundling of Services, Journal of Marketing, April, 1987. http://dx.doi.org/10.2307/1251130

Kahneman D., Knetsch J., Thaler R., Fairness as a Constraint on Profit Seeking: Entitlements in the Market, The American Economic Review, September, 1986.

Kimes S., The basic of Yield Management, Cornell Hotel Restaurant Administration Quarterly, November, 1989.

http://dx.doi.org/10.1177/001088048903000309 
Lee K., Ng I., Advanced Sale of Service Capacities: a Theoretical Analysis of the Impact of Price Sensivity on Pricing and Capacity Allocations, Journal of Business Research, n. 54, 2001. http://dx.doi.org/10.1016/S0148-2963(00)00119-3

Marn M., Rosiello R., Managing Price, Gaining Profit, Harvard Business Review, Sept/Oct, 1992.

Romani S., L'analisi del comportamento del consumatore per la determinazione del prezzo di vendita di prodotti e servizi, Franco Angeli, Milan, 2000.

Rook D. W., The Buying Impulse, Journal of Consumer Research, n. 14, 1987. http://dx.doi.org/10.1086/209105

Smith B. C., Leimkuhler J., Darrow R., Yield Management at American Airline, Interfaces 22, Gen/Feb, 1992.

http://dx.doi.org/10.1287/inte.22.1.8

Stremersch S., Tellis G., Strategic Bundling of Product and Prices: a New Synthesis for Marketing, Journal of Marketing, January, 2002.

http://dx.doi.org/10.1509/jmkg.66.1.55.18455

\section{Notes}

${ }^{1}$ For public services companies, payments by users, as well as being a collaboration in covering costs, are included within the sphere of economic policy targets in the management of income redistribution amongst taxpayers and at the same time the reduction of public expense; in this sense, more often than not, the tariff system is regulated and concerns the wider sphere of State intervention in economic activities whether they be carried out by state entities or private parties.

${ }^{2}$ This is the case with networked services like electricity with DL 99/1999, and with the railways with EU directive 2001/12/UE.

${ }^{3}$ Cappiello G., Auction Pricing and Market Space Competition, Symphonya. Emerging Issues in Management (symphonya.unimib.it), n. 1, 2002.

${ }^{4}$ Brondoni S. M, Global Markets and Market-Space Competition, Symphonya. Emerging Issues in Management (symphonya.unimib.it), n. 1, 2002. cit.

${ }^{5}$ A review of the principal methods is to be found in: Mc Afee R., Mc Millan J., Auctions and bidding, Journal of Economic Literature, June 1987; Lucking Reiley D., Auctions on the Internet: what's being auctioned and how?, Working Paper Vanderbilt University, 1999; Gilli M., I giochi e lo scambio. Elementi per una discussione sull'uso delle aste nella teoria e nella politica economica, Economia e Politica Industriale, n. 110, 2001.

${ }^{6}$ Corniani M., Demand Bubble Management, Symphonya. Emerging Issues in Management (symphonya.unimib.it), n. 1, 2002. 